\title{
Septuagintas betydning for udfoldelsen af nytestamentlig teologi
}

\author{
Anden del: Udvalgte eksempler på skriftsteder og \\ enkeltord $^{1}$ \\ Professor dr.theol. \\ Mogens Müller, Københavns Universitet
}

\begin{abstract}
This second part of an article on the significance of the Septuagint for the development of New Testament theology takes up a series of text examples and single terms where the Septuagint version of the Old Testament has influenced the New Testament. One outstanding example in the first category is the concept of virgin birth in Matthew 1,23 that derives from Isaiah 7,14. To the second category belongs not least the Septuagint's rendering of the tetragram by means of kúptos, Lord, a rendering that also made it applicable to Jesus.
\end{abstract}

Key words: Virgin birth - Book of Jonah - Lord - glory - gospel - law - covenant - justice - love - the peoples - nighbour.

\subsection{Citater}

Vi har allerede berørt eksempler på, hvordan den gamle græske oversættelse for de nytestamentlige forfattere har bestemt deres grundlæggende teologiske sprogbrug og undertiden muliggjort en inddragelse af Skriften, som den hebraiske ordlyd ikke havde tilladt. ${ }^{2}$ R. Timothy McLay opregner i The Use of the Septuagint in New Testament Research en række af "the usual suspects", når det gælder skriftord i Det Nye Testamente, der afspejler en græsk tekst, der er forskellig fra den masoretiske tekst. I denne sammenhæng vil vi begrænse os til et par af de steder, hvor alene den græske ordlyd muliggør den nytestamentlige

\footnotetext{
1. Jeg vil benytte lejligheden her til at rette følgende fejl i denne artikels første del i forrige hefte (DTT 79 (2016) 139-151: 148 l. 12 f.o. stryges "sich", og i 1.15 f.o. et "at"; 149 n. 27 skal det være "Dichotomy, og s. 150 n. 28 skal sidetallene være 717-730.

2. Den fulde registrering af Vetus Testamentum in Novo foreligger i det af Hans Hübner grundlagte værk med denne titel, hvoraf er udkommet Band 2. Corpus Paulinum (Göttingen: Vandenhoeck \& Ruprecht 1997) og Band I,2. Evangelium Johannis (i samarb. m. Antje \& Michael Labahn, 2002), mens Band 1,1. Synoptische Evangelien og Band 3. Katholische Briefe und Apokalypse stadig er under udgivelse.
} 
brug. ${ }^{3}$ Dernæst vil vi undersøge en række af de vigtigste gloser, der i væsentlig grad henter deres betydning i Septuaginta. ${ }^{4}$

\section{1 .1}

I tilfældet med 1 Kor 2,16, hvor Paulus ved at citere Es 40,13 i LXX's skikkelse får voũ $\varsigma$ i stedet for $\pi v \varepsilon \tilde{u} \mu \alpha$, er det så langt fra - som Otto Michel mente det - at være det næstbedste, at det faktisk lægger op til fortsættelsen, hvor apostlen siger, at han er i besiddelse af voṽv X lus' opfattelse af det at være i Kristus som noget, der også er bestemmende for livsførelsen. ${ }^{5}$

\subsection{2}

Det måske bedst kendte eksempel er Matt 1,23 om jomfrufødslen. Havde oversætteren/oversætterne af Es 7,14 ikke valgt $\dot{\eta} \pi \alpha \rho \theta \varepsilon \dot{\varepsilon} v o \varsigma$ til at gengive det העָלָכָה som i sig selv blot betyder "den unge kvinde", er der faktisk god grund til at tro, at der ikke var opstået nogen forestilling om en jomfrufødsel. På den anden side har det efter alt at dømme netop været forekomsten i Es 7,14 af “jomfruen”, der har bevirket inddragelsen af dette sted i Matthæusevangeliets række af opfyldelsescitater. For denne forestilling kendes fra Det Nye Testamente alene fra Matt 1,23, der citerer Es 7,14 med LXX's ordlyd, samt fra Lukasevangeliet, der genskriver dette motiv, dog uden skriftreference (se Luk 1,27, hvor glosen $\pi \alpha \rho \theta \varepsilon \dot{v}$ o $\zeta$ forekommer, samt 1,31, der er et skjult citat fra Es 7,14, men hvor "jomfruen" er udeladt, fordi udsagnet er omsat til direkte tiltale i 2. person). Så hvad der ellers var grunden til valget af $\pi \alpha \rho \theta \varepsilon \dot{\varepsilon}$ o $\varsigma$ i oversættelsen af Es $7,14,{ }^{6}$ har dette

3. Se R. Timothy McLay, The Use of the Septuagint in the New Testament (Grand Rapids, Michigan: Eerdmans 2003), 148-158. Desuden vil jeg også inddrage det eksempel, som McLay, 159-169, giver på en mere indirekte teologisk indflydelse, nemlig i skikkelse af en frugtbargørelse af Jonas' Bog i Matthæusevangeliet

4. Det vil dog ske i en anden rækkefølge end hos McLay, nemlig en tilstræbt kronologisk.

5. Jf. McLay (2003), 152f: "We do not want to make exagggerated claims about the significance of the citation of Isaiah 40:13 for the development of Paul's thought, but it is tantalizing to suggest that 1 Corinthians 2:16 offers insight into the formation of the way in which the Apostle established the connection between the mystical union of the believer in Christ and the way one is called to live: we have the mind of Christ."

6. Se foruden diskussionen i M. Müller, Kommentar til Matthausevangeliet. DKNT 3 (Århus: Aarhus Universitetsforlag 2000), 90-92, og henvisningen dér til M. Rösel, "Die Jungfrauengeburt der endzeitlichen Immanuel Jesaja 7 in der Übersetzung der Septuaginta", JBTh 6 (1991) 135-151: Ronald L. Troxel, "Isaiah 7,14-16 Through the Eyes of the Septuagint", EThL 79 (2003), 1-22. 
skriftord netop i kraft af jomfruen haft en kolossal virkningshistorie. ${ }^{7}$ Selv om det er det mest nærliggende at tro, at Lukasevangeliet i sin genskrivning i sidste instans bygger på Matthæusevangeliet, er det ikke muligt at sige noget om forestillingens liv og udvikling i den mellemliggende periode. Men det er påfaldende, den i Luk 1,31 alene implicit forbindes med Esajas-profetien. Og den fortolkning har været fremme, at jomfrufødslen for denne forfatter, der også fører sin slægtstavle helt tilbage til Adam, søn af Gud (Luk 3,38), betyder en helt ny begyndelse i uafhængighed af jødedommen og patriarkerne, hvorfor den kommer dermed ud på ét med en forkastelse af Israel som Guds udvalgte folk. ${ }^{8}$

\subsection{3}

Mindre oplagt er det, når McLay som eksempel også inddrager brugen af Dan 7,13 i Mark 13,26/Matt 24,30 med flere steder. Ganske vist er der efterhånden flere, der har udpeget den åbenbare identifikation af den menneskelignende med den gamle af dage i en række Septuaginta-håndskrifter som den oprindelige. Således læser disse tekstvidner i v. $13 \mathrm{c} \omega \varsigma$ i stedet for $\tilde{\varepsilon} \omega \varsigma$, så teksten lyder: $\dot{\varepsilon} \theta \varepsilon \omega ́ \rho 0 v v$

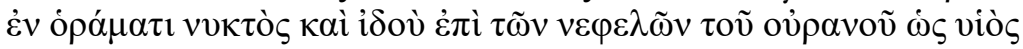

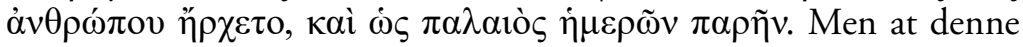
oversættelse skal have været baggrunden for en kristologisk forståelse af udtrykket i evangelierne, er en problematisk antagelse, hvad enten denne forstålse føres tilbage til Jesus selv eller til hans disciple. ${ }^{9}$ For det er og bliver den mest sandsynlige antagelse, udtrykket "menne-

7. Som McLay, The Use of the LXX, 149, konstaterer det: "Innumerable heresies, controversies, decisions of ecumenical church councils, and so much of the terminology of the Early Church such as theotokos and christotokos are inextricably linked to the interpretation of Matthew 1:23, which utilizes the Greek."

8. Se hertil Gitte Buch-Hansen, "The Politics of Beginnings - Cosmology, Christology and Covenant: Gospel Openings Reconsidered in the Light of Paul's Pneumatology", Mark and Paul. Comparative Essays Part II. For and Against Pauline Influence in Mark, red. Eve-Marie Becker, Troels Engberg-Pedersen \& Mogens Müller BZNW 199 (Berlin: de Gruyter 2014), 213-242, 238, hvor det bl.a. hedder: "In Mary's womb God creates a brand new beginning and a new $\gamma \dot{\varepsilon} v o \varsigma$ - race or family - independent of Judaism and its patriarchs. ... We may conclude that the narrative of the virgin birth is no innocent story; above all, it is a symbol of the rejection of Israel as God's chosen and privileged nation." Se også n. 47, hvor Buch-Hansen henviser til Justin, Dialog med Jøden Tryfon 135,3 for denne forståelse.

9. Foruden McLays argumentation (2013), 155-158, se Mogens Müller, The Expression 'Son of Man' and the Development of Christology. A History of Interpretation. CIS (London: Equinox 2008) 344-345. Se siden desuden diskussionen i Siegfried Kreuzers "Exkurs: Papyrus 967, seine Besonderheiten und seine Bedeutung", Septuaginta Deutsch. Erläuterungen und Kommentare zum griechischen Alten Testament. Band II. Psalmen bis Daniel, red. Martin Karrer \& Wolfgang Kraus (Stuttgart: Deutsche Bibelgesellschaft 2011), 3005-3007. 
skesønnen" i evangelierne går tilbage til en aramaisk talemåde, hvor

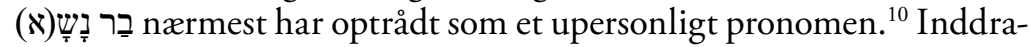
gelsen af Dan 7,13 er således ikke udgangspunktet, men først sket i løbet af traditionsprocessen, nemlig på et tidspunkt, hvor man havde brug for skriftsteder, der kunne beskrive den ophøjede Kristus. ${ }^{11}$ En fortolkning af udtrykket ud fra Dan 7,13 med den særlige læsemåde med $\dot{\omega} \varsigma$ forudsætter altså, at menneskesønnen i evangelierne er en kristologisk titel, hvad der er adskilligt, der taler imod. ${ }^{12}$

\subsection{4}

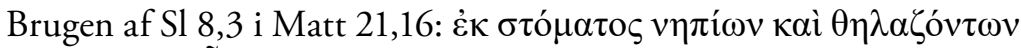


børns og diendes mund har du grundlagt et værn mod dine modstandere", ja, man må ligefrem tro, at det er LXX's "lovsang”, der har skabt fortællingen om episoden i templet. Forfatteren til Matthæusevangeliet har den i hvert fald ikke fra Markusevangeliet.

\section{1 .5}

Inddragelsen af Am 9,11-12 i ApG 15,16-18 ${ }^{13}$ er endnu et klart eksempel på en forskel, der har gjort teksten brugbar i en nytestamentlig sammenhæng. Således er MT's "så at de kan tage hele Edom i besiddelse og alle de folk, som mit navn er nævnt over, siger Herren, og han vil gøre det” i den græske oversættelse blevet til ő $\pi \omega \varsigma$



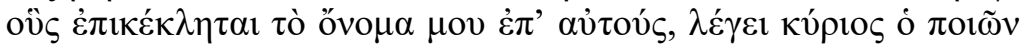
$\tau \alpha \tilde{\tau} \tau \alpha$. For forfatteren til Apostlenes Gerninger, der lader dette citat indgå i Herrens bror, Jakobs tale ved apostelmødet, kan derved lade Jesu opstandelse være opfyldelsen af Herrens løfte om at genopbygge Davids faldne hytte med det formål, at også alle de øvrige mennesker, dvs. alle ikke-jøderne, kan søge Herren - i sin gengivelse indskyder han her det objekt, som mangler i LXX, nemlig tòv кúpıov. Ved at objektet i MT således bliver subjekt i LXX ændres i det hele taget

10. For en kort sammenfatning se Mogens Müller, "Er løsningen på 'menneskesøn'-problemet fundet? En anmeldelsesartikel om Maurice Casey's nye 'menneskesøn'bog”, DTT 71 (2008), 42-49. Optrykt i Müller, Skriften i Skriften. Mellem tradition og reception. Fjorten Afhandlinger, Publikationer fra Det Teologiske Fakultet 22 (København 2011), 181-188.

11. Se Mogens Müller, "Biografiseringen af den opstandne og ophøjede Kristus", Frelsens biografisering, red. Thomas L. Thompson \& Henrik Tronier, FBE 13 (København: Museum Tusculanum 2004), 135-146.

12. Se Müller, The Expression "Son of Man" and the Development of Christology: A History of Interpretation, SW 11 (London: Equinox 22012), passim.

13. McLay behandler ikke dette sted i forbindelse med de andre, men som et paradigmatisk eksempel i begyndelsen af McLay (2003), 17-25. 


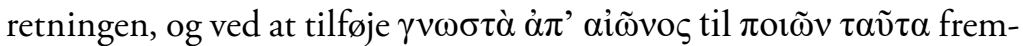
hæves udsagnets profetiske karakter: At dette skulle ske, blev således gjort bekendt fra evighed af.

\subsection{6}

Endelig skal også et mere sofistikeret eksempel nævnes. McLay (2003, 162-165) har således peget på, at LXX's gengivelse af Jonas' salme er en sandsynlig baggrund for Matthæusevangeliets eksplicitte og implicitte inddragelse af Jonasbogen på en række vigtige steder i dets tydning af Jesu død. Således citeres hele Jon 2,1 i Matt 12,40, men også andre udsagn i salmen synes tænkt med. For ikke alene

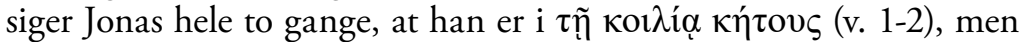

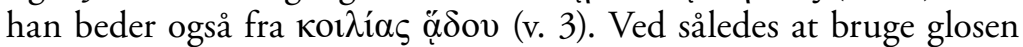
$\kappa o \iota \lambda i ́ \alpha$ alle tre steder, tydeliggør LXX den identifikation af havdyrets bug med dødsriget (Hades), som også er indeholdt i den hebraiske



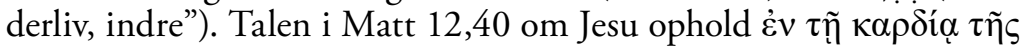
$\gamma \tilde{\eta} \varsigma$ kan desuden indbyde til et "medhør" af Jon 2,4 og 7, hvor det det

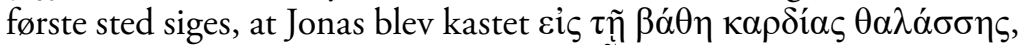



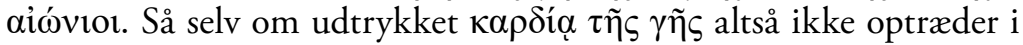
Jonas' salme, "its lexical components are employed as part of the metaphorical imagery that is associated with hades/Sheol" (Mclay 2003, 161). Også selve opstandelsen, som ganske vist ikke her eksplicit nævnes, men synes tænkt med i tidsangivelsen "tre dage og tre nætter", kan Matthæusevangeliets forfatter have haft med i sin forstålse af Jon 2, nemlig ud fra v. 7b: "Og lad mit livs undergang stige op, Herre,


den hebraiske tekst blot har: "Men du, Herre min Gud, løftede mig op fra graven." Anvendelsen af både $\kappa \alpha \tau \alpha \beta \alpha i v \omega$ og $\alpha v \alpha \beta \alpha i v \omega$ forudsætter en nedfart til dødsriget og kan desuden pege på, at det er indefra, Jesus bryder de slåer, der ellers skulle have holdt evigt.

I forlængelse heraf peger McLay på, at afhængigheden af Jonas' Bog i Matt 16,18 - bemærk også gentagelsen af begrebet "Jonas' tegn" i 16,4 - desuden synes at afspejle sig i tilnavnet til Peter, B $\alpha \rho \iota \omega v \tilde{\alpha}$, hvad der lægger op til, at talen om $\pi \hat{\lambda} \lambda \alpha \mathrm{\alpha}$ ő $\delta o v$ i v. 18 ikke skal forstås som en omskrivning for de gudsfjendtlige kræfter, men - mere bogstaveligt - om de porte til Dødsriget, som Jesus ved sin opstandelse sprænger - jeg vil altså mene - indefra. Dette motiv udfoldes så siden i de ellers gådefulde udsagn i Matt 27,51b-53 om de hensovede helliges legemer, der gik ud af deres grave og efter Jesu opstandelse viste sig for mange i den hellige by. 


\subsection{Enkelte betegnelser og begreber}

Det er klart, at der, hvad angår betegnelser og begreber, alene kan blive tale om et udvalg, som så til gengæld forhåbentlig er repræsentativt. Og netop i tilfældet med enkeltord bliver det tydeligt, at den nye kontekst, som er skabt af Kristus-troen, også kan bidrage til det betydningsindhold, de forskellige gloser får i nytestamentlige skrifter, og som danner udgangspunkt for deres brug hos senere kristne forfattere. Som vi skal se det, har det ganske vist i nogle tilfælde været diskuteret, hvorvidt den nytestamentlige sprogbrug her primært har haft sin baggrund i Septuaginta, eller om indflydelsen herfra først gjorde sig gældende hen ad vejen. I dette spørgsmål hælder de fleste dog nok i dag til, at det var det første, der gjorde sig gældende.

\subsection{1 кúpios}

Det vel vigtigste eksempel på en oversættelse, der fik stor betydning for udviklingen af nytestamentlig teologi, er Septuagintas gengivelse af gudsnavnet Jahweh med kúpıos. ${ }^{14}$ Allerede i Genesis-LXX skelner oversætterne mellem Gud (ó $\theta \dot{\delta}$ ○s) som gengivelse af 'elohim og

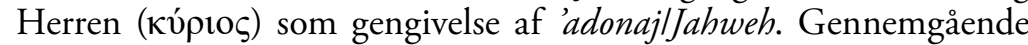
foretrækkes sidstnævnte betegnelse, hvor det gælder straffeaspektet, mens førstnævnte navn især forbindes med barmhjertighed. ${ }^{15}$ Selv om de ældste LXX-håndskriftfragmenter på gudsnavnets plads bringer tetragrammet med hebraiske bogstaver, er der grunde til at antage, at LXX her afspejler den omstændighed, at man allerede i 200-tallet f.Kr. i oplæsningen erstattede Jahweh med 'adonaj, hvad der naturligt nok blev gengivet kúpıs. Det blev til gengæld aldrig brugt til at oversætte $b a^{\prime} a l$, hvad der ellers havde været nærliggende.

Denne transformation af det græske kópıo̧ til et "navn" fik store konsekvenser i den tidligste græsktalende kristendom, som bekendte sig til den opstandne ikke mindst med netop denne betegnelse (se fx Fil 2,11), idet den dog også fortsat om end kun ca. en tredjedel så mange gange blev benyttet om Gud, som oftest i skriftcitater eller i

14. Det følgende bygger først og fremmest på Martin Rösel, Adonaj-warum Gott "Herr" genannt wird, FAT 29 (Tübingen: Mohr Siebeck 2000), især 222-230. Desuden samme, "Die Übersetzung der Gottesnamen in der Genesis-Septuaginta", Ernten was man sät, red. D.R. Daniels, U. Glessmer \& M. Rösel. FS Klaus Koch (Neukirchen-Vluyn: Neukirchener Verlag 1991), 357-377; "Theo-logie der griechischen Bibel. Zur Wiedergabe der Gottesaussagen im LXX-Pentateuch", Vetus Testamentum 48 (1998), 49-62; "Towards a "Theology of the Septuagint”, Septuagint Research. Issues and Challenges in the Study of the Greek Jewish Scriptures, red. W. Kraus \& R.G. Wooden, SBL.SCSS 53 (Leiden: Brill 2006), 239-252, især 245-248. 15. Ganske vist forholder det sig i dette spørgsmål omvendt hos Filon. 
referencer dertil. ${ }^{16}$ Så selv om brugen af kúpıo̧-betegnelsen om Jesus også kan have haft en polemisk brod mod denne verdens herskere (jf. 1 Kor 8,5), ${ }^{17}$ taler al sandsynlighed for, at den tidligste menigheds inddragelse af den i kulten har sit udspring netop i Septuagintas gengivelse af 'adonaj og ikke, som det tidligere var en udbredt opfattelse, i hellenistisk kult. ${ }^{18}$

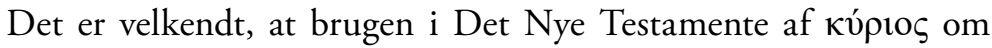
såvel Gud som Jesus, hvor "titlen" fx i Matthæusevangeliet konsekvent og alene anbringes $\mathrm{i}$ munden på troende disciple $\mathrm{i}$ tiltale til Jesus - således ikke Judas -, en række steder, ikke mindst hos Paulus, rejser spørgsmålet om, om det er den ene eller den anden, der er tale om. At titlen kunne bruges i én sætning om begge, ser vi i perikopen med samtalen om, hvis søn Kristus er, hvor Sl 110(109),1 citeres med


12,36 med par.).

En særlig omstændighed er, at oversættelser af det græske кúpı også helt har fået lov til at fortrænge tetragrammet i såvel Vulgata som i praktisk taget alle moderne oversættelser fra Reformationen og frem. GT-oversættelsen af 1931 indførte ganske vist her at skrive Herren med kapitæler (Herren), hvad man dog gik bort fra igen i 1992-oversættelsen. ${ }^{19}$ Karakteristisk nok gennemførte Frants Buhl at

16. Ifølge Rösel, Adonaj, 224, bliver Jesus i NT betegnet som kúpı̋ৎ ca. 468 steder, mens betegnelsen gælder Gud ca. 156 steder. Disse tal har Rösel fra en ikkeoffentliggjort artikel af Christfried Böttrich.

17. Se hertil fx Heike Omerzu, "Paulus als Politiker? Das paulinische Evangelium zwischen Ekklesia und Imperium Romanum”, Logos - Logik - Lyrik. Engagierte exegetische Studien zum biblischen Reden Gottes, red. Volker A. Lehnert \& Ulrich Rüsen-Weinhold, FS Klaus Haacker, Arbeiten zur Bibel und ihrer Geschichte 27 (Leipzig: Evangelische Verlagsanstalt 2009), 267-287, især 270.

18. Klassisk er her opfattelsen i Wilhelm Bousset, Kyrios Christos. Geschichte des Christusglaubens von den Anfängen des Christentums bis Irenaeus, FRLANT 21 (Göttingen: Vandenhoeck \& Ruprecht 1913, ${ }^{2} 1921={ }^{6} 1967$ ), især 98-104, hvor det erklæres, at denne brug af titlen om Jesus ikke kan være opstået på palæstinensisk grund, og endvidere bestridt (101), “daß man i den hellenistischen Urgemeinden


eigenen Wurzeln. Aber nachdem sich einmal diese Bezeichnung für Christus eingebürgert hatte, las man sie natürlich in das Alte Testament hinein og bezog den heiligen Gottesnamen auf Jesus von Nazareth."

19. I prøveoversættelserne, der gik forud for 1992-oversættelsen, forsøgte man sig i bindet med Samuels- og Kongebøgerne (1986) med at gengive tetragrammet med Jahve. Det var allerede blevet overvejet i prøveoversættelsen af Salmernes Bog (1977). Men selv om Bibelselskabet vist var med på det, gjorde man det dog ikke. Som det hedder i forordet: "Men brugen af navnet Jahve er stødt på indvendinger, der i alt væsentligt er begrundet ud fra hensynet til dansk bibeltradition og forholdet til Det Nye Testamente, og forsøget blev derfor opgivet.” I 1992-oversættelsen optræder Jahve-navnet dog i alt 13 gange, nemlig i sammenhænge, der taler om 
gengive tetragrammet med Jahve i den af ham udgivne oversættelse af GT fra 1910.

\subsection{2 $\delta$ ó $\xi \alpha$}

Et udtalt eksempel på en græsk glose, der i bibelsk sammenhæng nærmest konsekvent optræder med en betydning, som stammer fra det hebraiske ord, som den gengiver, er $\delta$ ó $\xi \alpha$ som gengivelse af כָ i betydningen herlighed. Denne særlige brug omfatter også det tilhørende verbum $\delta$ o $\xi \alpha \dot{\zeta} \omega$. Især medvirkende kan her brugen af $\delta$ ó $\xi \alpha$ i forbindelse med gengivelsen af כבוֹ i Sinaj-perikopen i Exodus, men også fx i kaldelsesvisionen i Es 6 have været. Det er således i denne særlige "bibelske" betydning, at $\delta$ ó $\xi \alpha$ optræder hos først Paulus og siden i de øvrige nytestamentlige skrifter, herunder ikke mindst Johannesevangeliet. ${ }^{20}$ Som det allerede fremgår af behandlingen i Kittels Theologische Wörterbuch zum Neuen Testament gælder det, at denne særlige brug ikke optræder hos Filon og Josefus, ${ }^{21}$ men som Jörg Frey konkluderer med hensyn til Paulus - men det vil så også gælde de øvrige nytestamentlige forfattere - "the apostle did not take his views of $\delta$ ó $\xi \alpha$ from a common usage of Hellenistic Judaism, nor from common usage in the Koine" (Frey 2014, 94). Denne brug er således virkelig et eksempel på Septuaginta-sprog.

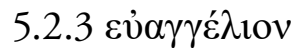

Som det også var tilfældet med кúpıos, har der i dele af forskningen været en stærk tendens til at se baggrunden for brugen af begrebet $\varepsilon \dot{\alpha} \alpha \gamma \gamma \varepsilon \dot{\lambda}$ เov i den omkringliggende verdens sprogbrug, hvor

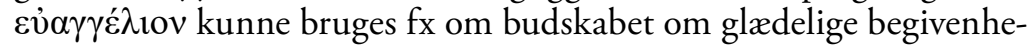
der (således fx af Josefus i Den Jødiske Krig 2. bog 420). ${ }^{22}$ Men selv


LXX ikke forekommer i singularis og i pluralis kun tre gange, alle i

\footnotetext{
Jahves navn som fx Es 42,8: “Jeg er Jahve, det er mit navn.” Jeg takker Bodil Ejrnæs for disse oplysninger. Se i øvrigt også hertil B. Ejrnæs, Skriftsynet igennem den danske bibels historie, FBE 6 (København: Museum Tusculanum 1995), 187 med note 9 .

20. Af den righoldige litteratur til dette emne skal der her alene henvises til Jörg Frey, "The Use of $\delta$ ó $\xi \alpha$ in Paul and John as Shaped by the Septuagint", Reception of Septuagint Words in Jewish-Hellenistic and Christian Literature, red. Eberhard Bons, Ralph Brucker \& Jan Joosten, WUNT 2/367 (Tübingen: Mohr-Siebeck 2014), 85104 , hvor også brugen i LXX gennemgås. For Johannesevangeliet, se dog desuden Jesper Tang Nielsen, Die kognitive Dimension des Kreuzes, WUNT 2/263 (Tübingen: Mohr-Siebeck 2009), 89-140.

21. Se ThWNT II (1935) 240. Det er Gerhard Kittel selv, der er forfatter til denne del af $\delta$ ó $\xi \alpha$-artiklen (235-258).
}

22. Se hertil fx Omerzu (2009), især 275. 
2 Bas/2 Sam (4,10; 18,22.25), i betydningen glædebudskab(er), gode

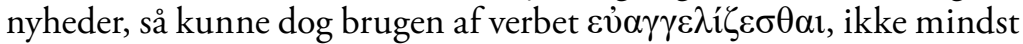
fire centrale steder i Deutero- og Tritojesaja $(40,9 ; 52,7 ; 60,6$ og 61,1) indbyde til en antagelse af, at Paulus' og de andre nytestamentlige forfatteres inddragelse af netop denne glose til at betegne frelsesbudskabet kunne have sin baggrund her. Mens der tidligere, $\mathrm{fx}$ hos Rudolf Bultmann, herskede skepsis med hensyn til denne afledning, ${ }^{23} \mathrm{kom}-$ mer Peter Stuhlmacher i monografien Das paulinische Evangelium fra 1968 til det resultat, at hvor den hellenistiske jødedom kun indirekte hører med til den nytestamentlige evangelieforkyndelses traditionshistorie, spiller Septuaginta her en mere betydningsfuld rolle. ${ }^{24}$

De to af de fire steder fra Deutero- og Tritojesaja optræder også i NT med verbalformen. Således finder vi Es 52,7 som et vigtigt led i Paulus' argumentation i Rom 10,14-18 for tesen i v. 13, der består


$\sigma \omega \theta \eta ் \sigma \varepsilon \tau \alpha$. For deri ligger der det kald til en forkyndelse også blandt ikke-jøder, der netop er indholdet af Paulus' apostolat. For ingen kan påkalde Herrens navn uden først at være kommet til tro. Og tro forudsætter nogen til at forkynde, og det forudsætter igen, at nogen bliver udsendt, hvad der så begrunder ordene fra Es 52,7: ஸ́


denne betydning ikke også kan udledes af den hebraiske tekst.

Men at oversætteren/oversætterne her valgte netop dette verbum, synes imidlertid at have været en i hvert fald medvirkende årsag til, at Paulus og siden ham andre nytestamentlige forfattere anvendte

23. Således fx repræsentativt Rudolf Bultmann, Theologie des Neuen Testaments (Tübingen: Mohr (Siebeck) ${ }^{5} 1965$ [1948-1953]), 89-90. Se desuden tidligere fx Einar Molland, Das paulinische Euangelion. Das Wort und die Sache. ANVAO, II. Hist.Filos Kl. 1934, Nr. 3 (Oslo: I kommisjon hos Jacob Dybwad 1934), 18-21.

24. Se Peter Stuhlmacher, Das paulinische Evangelium. I. Vorgeschichte (alt som udkom), FRLANT95 (Göttingen: Vandenhoeck \& Ruprecht 1968), 179: "Die

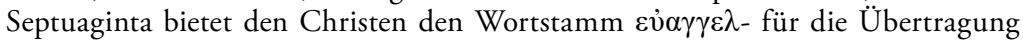
der Wurzel בשר einheitlich dar, aber nicht nur den Wortstamm, sondern auch das heilsgeschichtliche Medium des (prophetischen) Gotteswortes, in welches der Wortstamm eingebettet ist. Wenn die zur Mission aufbrechenden Christen den Heiden das (alttestamentliche) Gotteswort verkünden, ihre Verkündigung heilsgeschichtlich begründen und diejenigen Elemente der בשר-Tradition, welche im aramäisch-sprachigen palästinensischen Christentum lebendig waren, ihrer eigenen Missionsverkündigung nutzbar machen wollten, waren sie jedesmal auf die Septuaginta angewiesen und auf deren Gebrauch der Ausdrücke $\varepsilon \dot{\alpha} \alpha \gamma \gamma \varepsilon \lambda i \zeta \varepsilon \sigma \theta \alpha 1$,

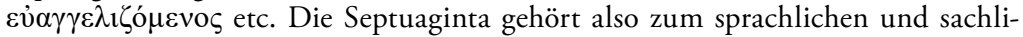
chen Fundamentalbestand des urchristlichen Evangeliums auch dann, wenn sie

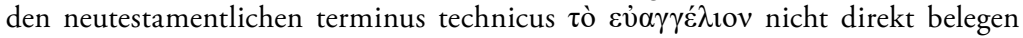
hilft." For en gennemgang af materialet i Septuaginta, se 154-164, og for et blik i forskningshistorien, se 7-55. 
glosen $\varepsilon \dot{\alpha} \alpha \gamma \varepsilon \dot{\lambda} \lambda$ iov som terminus technicus for frelsesbudskabet og derfor det tilsvarende $\varepsilon \dot{\alpha} \alpha \gamma \gamma \varepsilon \lambda i \zeta \varepsilon \sigma \theta \alpha \mathrm{l}$ om forkyndervirksomheden. Siden, i Luk 4,18, finder vi Es 61,1-2, som forventeligt i LXX's skikkelse, som den tekst, Jesus læser op ved sin såkaldte tiltrædelsespræ-

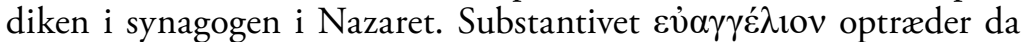
også i det ældste evangelium som en sammenfattende betegnelse for frelsesbudskabet (Mark 1,1.14.15; 8,35; 10,29; 13,10; 14,9 [16,15]), en sprogbrug forfatteren til Matthæusevangeliet overtager en række steder, dog de tre ud af de fire steder med kvalifikationen $\tau \tilde{\eta} \varsigma \beta \alpha \sigma \imath \lambda \varepsilon i ́ \alpha \varsigma$ $(4,23 ; 9,35 ; 24,14)$ og kun ét sted absolut $(26,13)$. Til gengæld optræder det hverken i Lukas- eller Johannesevangeliet, idet førstnævnte dog har verbet 10 steder (+ 15 steder i ApG.)

\section{2 .4 ó vó $\mu$ os}

Vi har allerede været inde på, at valget af ò vó $\mu$ o som den gennemgående gengivelse af תרוֹ betyder, at alene en del af dette hebraiske begrebs langt videre betydningsindhold end "lov" kommer til udtryk..$^{25}$ Den omstændighed, at det græske vó $\mu$ o adskilligt oftere end det hebraiske begreb og altid i singularis og som betegnelse for Guds eneste lov, gør, at det i den græske "Bibel" i højere grad end i den hebraiske kommer til at stå som det sammenfattende udtryk for Guds vilje og det integrerende element i jødisk religion. Således bidrager denne gengivelse til den etiserende tendens i forståelsen af tora, som kendetegner Septuaginta. Martin Rösel har endda hævdet, at det er passende i denne forbindelse af tale om en "NomosSoteriologie" (2007, 147). Men selv om Rösel kan følge C.H. Dodds og Klaus Bergers negative dom over gengivelsen af tora med ó vó $\mu$ os, finder han dog oversættelsen "unmittelbar einleuchtend. Allerdings verliert nomos im Griechischen Bereich die kultischen Dimensionen und damit den Bezug zur Heiligkeit, im Gegenzug wird er über die Verwendung in philosophischen Schriften mit logos und nous parallelisiert, so dass sich die genannte Erweiterung des Bedeutungsspektrums zu umfassenden Weltordnungsvorstellung erklären lassen könnte" (ibid.).

\footnotetext{
25. Se hertil fx Martin Rösel, "Nomothesie. Zum Gesetzesverständnis der Septuaginta", Im Brennpunkt: Die Septuaginta. Band 3: Studien zur Theologie, Anthropologie, Ekklesiologie, Eschatologie und Liturgie der Griechischen Bibel, red. H.-J. Fabry \& D. Böhler, BWANT 174 (Stuttgart: Kohlhammer 2007), 132-150. Af anden relevant litteratur til dette spørgsmål kan nævnes: A.F. Segal, "Torah and nomos in Recent Scholarly Discussion", i samme, The Other Judaisms of Late Antiquity. Brown Judaistic Studies 127 (1987), 131-145; F. Austermann, Von der Tora zum Nomos. Untersuchungen zur Übersetzungsweise und Interpretation im SeptuagintaPsalter, MSU 27 (Göttingen: Vandenhoeck \& Ruprecht 2003).
} 
Selv om andre betydninger stadig kan optræde som $\mathrm{fx}$ i betegnelsen ó vó ${ }_{0}$ o for Mosebøgerne som i Gal 4,21 og Matt 5,17 og for Skriften i sin helhed i 1 Kor 14,21, hvor det drejer sig om et citat fra Es 28,1112 , optræder ó vó $\mu$ o i langt de fleste tilfælde i betydningen "loven"

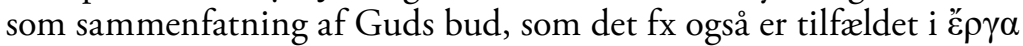
vó $\mu$ ov som teknisk betegnelse for de bestemmelser, der gør jøden til jøde (ibid.). ${ }^{26}$

\section{$5.2 .5 \delta 1 \alpha \theta \eta \dot{\kappa \eta}$}

Også valget af $\delta ı \alpha \eta \dot{\kappa} \eta$ som gengivelse af det hebraiske בְרִ har bidraget til en understregning af asymmetrien i forholdet mellem de to parter, Gud og folk. ${ }^{27}$ Det afspejler sig i analogien med et menneskes testamente, der endelig siden på latin simpelt hen bliver betegnelsen for pagten, selv om Vulgata i fx Jer 31,31 gengiver med foedus. I Gal 3,15.17; 4.24 m.fl.st. oversættes $\delta 1 \alpha \theta \eta \dot{\kappa} \eta$ således i Vulgata med testamentum/testamenta. En i udgangspunktet måske lige så nærliggende gengivelse af det hebraiske kunne have været $\sigma v v \theta \eta \dot{\kappa} \eta$, der ganske vist ikke ville ophæve asymmetrien, men stærkere betone gensidighedsforholdet. Der er også blevet peget på, at pagt langt fra er den mest oplagte gengivelse af $\delta \iota \theta \eta \dot{\kappa}\rceil$ i Hebræerbrevet, der i øvrigt er det nytestamentlige skrift, hvor denne glose optræder hyppigst, nemlig med 17 af de i alt 33 belæg. For på den måde, som den gamle og den nye $\delta\llcorner\alpha \theta \dot{\kappa} \kappa \eta$ i Hebræerbrevet stilles op over for hinanden, og hvor de to først og fremmest angår ypperstepræstetjenesten, er det mest nærliggende at oversætte glosen med "forordning", ${ }^{28}$ hvad der understreger det asymmetriske.

26. Se hertil især de mange bidrag til denne diskussion fra Michael Bachmanns hånd, fx “ Was für Praktiken? Zur jüngsten Diskussion um die ě $\rho \gamma \alpha$ vó $\mu$ ov”, NTS 55 (2009) 35-54; optrykt i samme, Von Paulus zur Apokalypse - und weiter. Exegetische und rezeptionsgeschichtliche Studien zum Neuen Testament, NTOA/SUNT 91 (Göttingen: Vandenhoeck \& Ruprecht 2011), 207-226.

27. Jf. Johannes Behms $\delta 1 \alpha \theta \eta \dot{\kappa \eta-a r t i k e l, ~ T h W N T ~ I I ~(1935), ~ 105-137, ~ 130,23-31: ~}$ "Verfügung, Willenskundgebung Gottes, sich in der Geschichte offenbarender, Religion stiftender Gotteswille - das ist der religiöse Begriff von $\delta\llcorner\alpha \theta \eta ் \eta$ in LXX, eine bedeutsame Zuspitzung des zugrunde liegenden hbr Begriffs unter Wahrung seines wesentlichen Vorstellungsinhalts. Durch Beibehaltung des Begriffs Bund, der schon בִ nִרית nicht deckte, durch Kompromißformeln wie Bundesverfügung, Vertragsordnung, Vertragsverfügung oder durch Einführung des der at.lichen Gedankenwelt fernliegenden Begriffs Testament wird der sprach- und religionsgeschichtliche Tat-

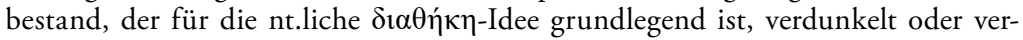
fälscht."

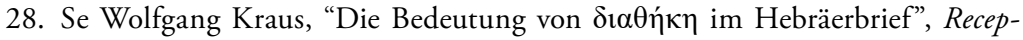
tion of Septuagint Words in Jewish-Hellenistic and Christian Literature, red. Eberhard Bons, Ralph Brucker \& Jan Joosten, WUNT 2/367 (Tübingen: Mohr-Siebeck 2014), 67-83, især 82: "Die Diatheke-Vorstellung hat im Hebr insofern eine spe- 


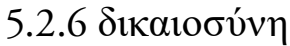



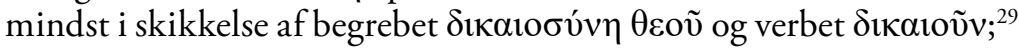
i evangelierne forekommer $\delta$ เ $\alpha 10 \sigma u ́ v \eta$ desuden syv gange i Matthæusevangeliet, slet ikke i Markusevangeliet og én gang i henholdsvis Lukas- og Johannesevangeliet. I LXX optræder ordstammen hyppigt og ikke alene i gengivelser af den hebraiske ordstamme צדק. Derigennem har begrebet fåt et nyt betydningsindhold i forhold til ikke-


gældende retfærdighed (iustitia distributiva). Men som ikke mindst


sonlig egenskab eller en forensisk tilkendt retfærdighed, men, som Ernst Käsemann kunne vise det, en magtsfære, hvori Gud skabende udfolder sin frelsesvilje. ${ }^{30}$

Hvad det vil sige, kan man se i inddragelsen af Hab 2,4 som uan-



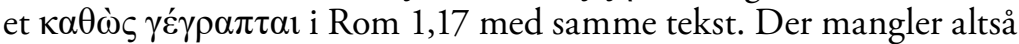
det $\mu$ ov, der findes det tredje sted, Hab 2,4 citeres i NT, nemlig Hebr 10,38 , hvor det er anbragt efter $\delta$ íkalos, hvor det dog i LXX er anbragt

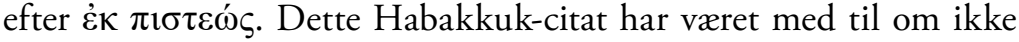
ligefrem at forme, så i hvert fald at bekræfte Paulus i hans forkyndelse af retfærdiggørelse af tro, om man nu vil knytte præpositionsleddet til subjektet eller til verbet. Det havde han ikke kunnet umiddelbart

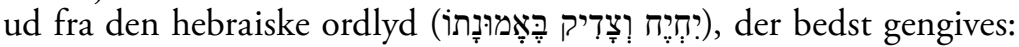
"men den retfærdige skal leve i trofasthed" (således prøveoversættelsen fra 1985; i DO 1992 blev det til: "men den retfærdige skal leve i tro"). For Paulus har læst stedet som en beskrivelse af den tro, der "kanaliserer" Guds skabende virksomhed ind i det enkelte menneske som en kraft, der er virksom i kærlighed (se Gal 5,6). Det er desuden

zifische Funktion: Jer 38[31] verheißt Sündenvergebung und begründet eine neue "Verfügung/Setzung", jenseits bzw. nach der älteren (überbotenen) Diatheke, durch welche die levitischen Priester eingesetzt wurden. Der Autor des Hebr verwendet die aus Jer 38 gewonnene Diatheke-Vorstellung um seine Hohepriester-Christologie in Gottes Verheißung, und d.h. biblisch, zu legitimieren. Dass die Argumentation des Hebr dann im weiteren Verlauf der Geschichte zur Begründung eines neuen Selbstverständnisses herangezogen werden konnte (Barn, Justin), gehört in dessen Wirkungs- oder besser: Rezeptionsgeschichte, aber noch nicht zur Absicht der Theologie des Auctor ad Hebraeos."

29. Se hertil Peter Stuhlmacher, Gerechtigkeit Gottes bei Paulus, FRLANT 87 (Göttingen: Vandenhoeck \& Ruprecht 1965, ${ }^{2} 1966$ ).

30. Se Ernst Käsemann, "Gottesgerechtigkeit bei Paulus", ZThK 58 (1961), 367378; optrykt i samme Exegetische Versuche und Besinnungen II (Göttingen: Vandenhoeck \& Ruprecht 1964), 181-193, men da også hans An die Römer. HNT 5a (Tübingen: Mohr (Siebeck) 1973), 21-27. 
indholdet af den retfærdighed, som Abraham tilkendes på grund af sin tro (Gen 15,6 i Gal 3,6; Rom 4,3; jf. dog også Jak 2,23).

\subsection{7 $\dot{\alpha} \gamma \alpha \dot{\pi} \pi \eta$}

I Septuaginta er det hebraiske substantiv אִ אָדָָָ gennemgående over-

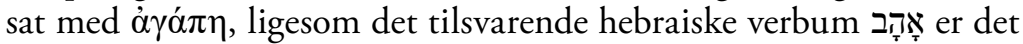
med $\alpha \gamma \alpha \pi \alpha ́ \omega$. Dermed har det uden for Bibelen sjældent forekommende græske ord modtaget den rige fylde, der ligger i den gammeltestamentlige kærlighedsforståelse. Ethelbert Stauffer kan ligefrem i $\alpha \gamma \alpha \pi \alpha ́ \omega$-artiklen i Theologisches Wörterbuch zum Neuen Testament skrive: "Man hat früher gemeint, $\dot{\alpha} \gamma \alpha \dot{\pi} \pi \eta$ sei ein neues Wort, erst durch die LXX geschaffen. Das ist kaum mehr wahrscheinlich.

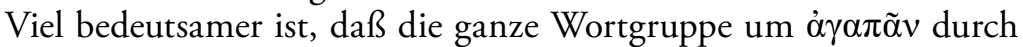
die griechische Übersetzung des AT erfüllt wird mit neuem Sinn" (ThWNT 1 (1933), 39). Under alle omstændigheder må det konstateres, at $\alpha \gamma \alpha \dot{\alpha} \pi \eta$ sammen med verbalformen spiller en helt central rolle i Det Nye Testamente, hvor vi dels møder begrebet som definition af

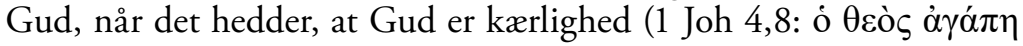

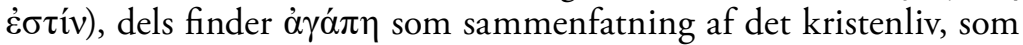
Gud skaber gennem evangeliet, hvad enten det sker som i kærligheden højsang i 1 Kor 13, men også i et udsagn som Matt 24,12 om kærligheden, der bliver kold i de fleste, eller i næstekærlighedsbuddet som opfyldelse af hele loven som i Rom 13,8-10 med konklusionen:

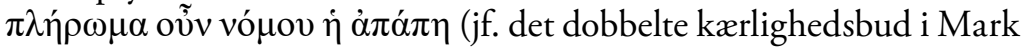
12,28-31 med par.).

\section{$5.2 .8 \tau \grave{\alpha}$ عै $\theta v \eta$}

Talen i LXX om folkeslagene ( $\tau \grave{\alpha} \varepsilon \ddot{\varepsilon} \theta v \eta$ ), der i modsætning til "folket" (ó $\lambda \alpha o ́ \varsigma)$ først siden skal inddrages i Guds frelsesplan, indgår uforkortet i Det Nye Testamente, der i dette bygger videre på tendensen i LXX til at indføre dette positive aspekt på de ikke-jødiske folk også på steder, hvor MT ikke har det. Det gælder fx den græske gengivelse af Es 42,1-4, der optræder som opfyldelsescitat i Matt 12,18-20, og

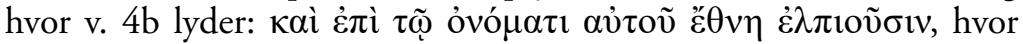
MT har "de fjerne øer venter på hans belæring (תרוֹ)". At folkesla-

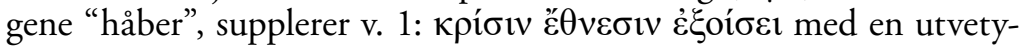
digt positiv tone, ${ }^{31}$ som der følges op på i v. 6 i såvel MT som LXX: "Jeg, Herren, har kaldt dig i retfærdighed, jeg tager dig ved hånden, jeg danner dig og gør dig til en pagt med folket, til et lys for folkene

31. Se hertil Frederik Poulsen, God, His Servant, and the Nations in Isaiah 42:1-9, FAT II 73 (Tübingen: Mohr Siebeck 2014), 118-162. 


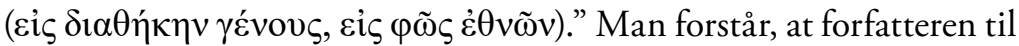
Matthæusevangeliet genfandt sin Kristus i denne tjener-sang.

Formodentlig er det den stadig mere konsekvente monoteisme, som i LXX bevirker denne påfaldende åbning over for de ikke-jødiske folkeslag, som også gør sig gældende i en række andre ændringer i LXX i forhold til MT. ${ }^{32}$ At det ikke betyder, at lovens betydning svækkes, kan aflæses i nogle ændringer i LXX's udgave af Sl 9,21 og 84(83),7. Førstnævnte sted lyder MT således: "Herre, indgyd folkene frygt, så

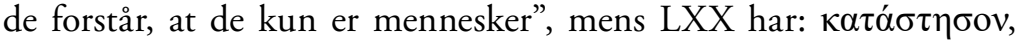

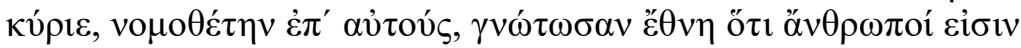
("indsæt en lovgiver over dem. Folkeslagene skal erkende, at de er mennesker"). Denne oversættelse forudsætter alene en ændring i vokaliseringen af מוֹרָרָ (מil (מil ), for at "frygt" kan blive til "lovgiver". Det er muliggjort af, at MT usædvanligt skriver dette substantiv med $\pi$ i stedet for med $\mathrm{k}$. Sidstnævnte sted (Sl 84(83) hedder det i MT: "efterårsregnen hyller den i velsignelse", hvor LXX har: кaì

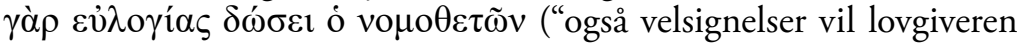
give”). Også her skyldes oversættelsen valget af en anden mulig betydning af det til grund liggende hebraiske מiוֹ. Frelsen for folkeslagene anskues i dette tilfælde som det at få del i loven. Man forstår Hans-Joachim Schoeps' tale om "die missionarische Abzweckung der Septuaginta". ${ }^{33}$

\subsection{9 ò $\pi \lambda \eta ́ \sigma i o v$}

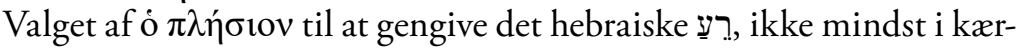
lighedsbuddet i Lev 19,18, har muliggjort den åbenhed for buddets gyldighed i forhold til også ikke-jøder, som ikke ligger i den hebraiske tekst. Denne begrænsning, der i fx Luk 10,29 kommer til orde i den lovlærdes spørgsmål om, hvem hans næste er, er i overensstemmelse med den afgrænsning, der åbenbart var karakteristisk i antik jødedom..$^{34}$ Under alle omstændigheder kan det konstateres, at LXX's


til dannelsen af selve fundamentet under den kristne etik, og med sin

32. Nævnes kan her fx Num 24,7.17, hvor dette aspekt indføres i Bileam-profetien i v. 7LXX.

33. Paulus. Die Theologie des Apostels im Lichte der jüdischen Religionsgeschichte (Tübingen: Mohr (Siebeck) 1959), 17. Se videre ovenfor i denne artikels første del.

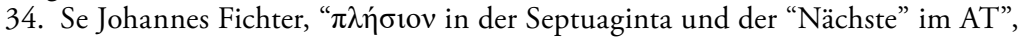
ThWNT VI (1959), 310-314, hvor det (313) hedder: "Spätere jüdische Rechtsauslegung hat eine ausdrückliche Begrenzung des Liebesgebotes vorgenommen; sie läßt es nur für Israeliten und Vollproselyten (...) gelten und schließt den Samaritaner, den Fremden, dh. Ausländer (...) und ..., den Beisassen, der sich innerhalb von 12 Monaten nicht der jüdischen Gemeinde angeschlossen hat, aus.” 
universalisme gør den det umuligt - i hvert fald ud fra Skriften - at sætte grænser.

\section{Slutning}

Som det allerede er fremgået, fik gengivelser af konkrete ord, begreber og udsagn afgørende betydning for udfoldelsen af nytestamentlig teologi. Jeg har ikke i denne omgang berørt spørgsmålet, om i hvilken grad LXX lægger mere op til messianske tolkninger end Biblia Hebraica ved enten at udtrykke en sådan direkte eller blot muliggøre den. ${ }^{35}$ Det vil føre for vidt her. Så til slut vil vi nøjes med kort at sammenfatte nogle af konsekvenserne af inddragelsen af LXX.

Hos Paulus og enkelte andre steder i de øvrige skrifter i NT kan vi iagttage, at den betydningen af de bagvedliggende hebraiske ord og begreber stadig kan klinge med. Men der er også eksempler på, at den valgte gengivelse gennem dens brug $\mathrm{i}$ andre kontekster eller selve dens ordlyd henter sit indhold fra den betydning, som glosen har i en ikke-bibelsk kontekst. Hvad der til en begyndelse endnu kunne være et vindue ind i den hebraiske bibelteksts betydningsunivers, mistede snart $i$ en ikke-jødisk hellenistisk kontekst disse konnotationer, en udvikling der yderligere accentueredes i oversættelser til ikke mindst latin, hvor fx iustitia Dei kunne være svært at forbinde med det, som

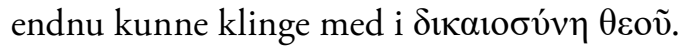

35. Til spørgsmålet om, hvorvidt Septuaginta har sin egen teologi, se igen Mogens Müller, "Theology in the LXX?" (jf. ovenfor n. 1 i denne artikels første del). 